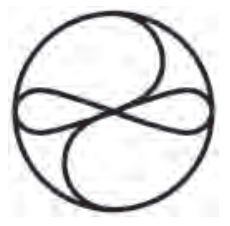

\title{
The Leading Way of
}

Changing Meaning

Sandra Sytsma

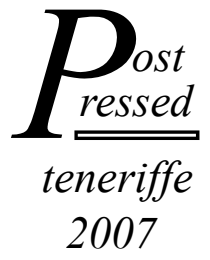


(C) 2007 Sandra Evelyn Sytsma. All rights reserved. Except for the quotation of short passages for the purposes of criticism and review, no part of this publication may be reproduced, stored in a retrieval system, or transmitted in any form or by any means, electronic, mechanical, photocopying, recording, or otherwise, without the prior written permission of the publisher or the Copyright Agency Limited.

National Library of Australia Cataloguing in Publication The leading way of changing meaning / author, Sandra Sytsma.

9781921214264 (pbk.)

Bibliography.

Information behaviour. Research. Learning and scholarship. Educational leadership.

025.524

This book is proudly published and produced in Australia.

Cover and book design: Jon Swabey

Artwork and cover photograph: Sandra Sytsma

Published by Post Pressed

324/50 Macquarie St

Teneriffe Qld 4005

www.postpressed.com.au

Typeset by Jon Swabey

Printed by Clark \& Mackay

Rocklea Qld 4107 


\section{Contents}

Acknowledgements ................................................... 9

Preface ................................................................... 11

1. Introduction ................................................... 13

2. Research Focus ................................................ 15

Research Problem:.......................................15

Rationale For Research:..................................23

Significance Of Research: ..................................28

Aims Of Research: ..........................................29

Research Questions: .......................................29

Limitations And Definitions Of Research:...................30

3. Research Framework.......................................... 35

Introduction: ................................................. 35

Changing: ...................................................

The Changing Way Of Being:.............................43

- Participation:..............................................47

- Moments of participation:...............................51

The Changing Way of Relating:.............................54

The Changing Way Of Knowing: ..........................63

The Changing Way Of Representing: .......................73

The Changing Way of Leading: .............................. 82

The Changing Way of Becoming: ..........................95

The Leading Way Of Changing Meaning: .................. 104

The Changing Way Of Researching:......................107

- The participative, socially constructed way of researching: .............................................111

- The open, generative way of researching: .........113

- The risking, vulnerable and trusting way of researching: ............................................117

- The truthful, valid way of researching: ..............121

The Changing Space Of Researching: .....................126

The Virtual Space Of Researching: ........................130 


\section{Researching The Leading Way Of Changing}

Meaning

Introduction: ........................................... 141

Methodology: ............................................. 144

Design Considerations: ................................... 150

Project Implementation: ................................. 154

Data Processing: ........................................... 162

- Sources informing data shaping: ..................... 163

- Changing form: ........................................ 170

- Reading the data: .................................. 173

- Themes: ............................................... 180

- Data summaries: .................................... 183

Analysis: .................................................. 213

- Changing: ............................................214

- The changing way of being: .......................... 215

- The changing way of relating:.......................217

- The changing way of knowing: ......................220

- The changing way of representing: ..................222

- The changing way of meaning: ......................224

- The changing way of leading: .........................226

- The changing way of becoming: ....................228

- The leading way of changing meaning: ............. 231

- The changing way of researching: ...................234

- The changing space of researching:.................. 241

- The virtual space of researching:................... 245

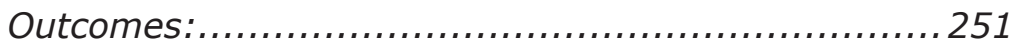

- Synthesis:........................................260

- Searching again:......................................268

Towards changing meaning in the leading way: ........ 276 Conclusions: ................................................ 282

Recommendations: ..................................... 289

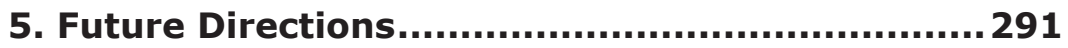

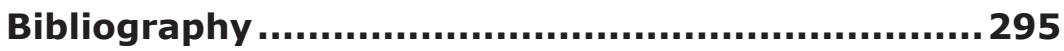




\section{List Of Figures And Tables}

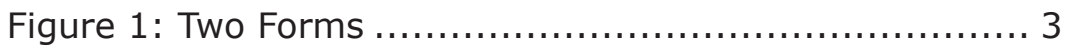

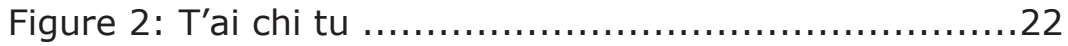

Figure 3: Aikido symbol .................................... 36

Figure 4: Grint's essentialist and non-essentialist leadership...84

Figure 5: Representing leading-changing-meaning ....... 165

Figure 6: Representing Data ............................... 169

Figure 7: Representing Data ............................ 294

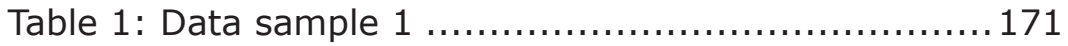

Table 2: Confections ..................................... 175

Table 3: Multiples ........................................ 175

Table 4: Parallels ....................................... 175

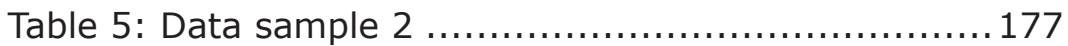

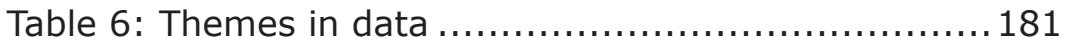




\section{Preface}

In studying leading as a way of changing meaning, this research documents a journey of inner exploration amongst five self-nominated leaders in education. In contrast to change limited by outer dimensional structure, changing meaning in an inner dimension was seen as the necessary complement in creating real difference in educators and in educating. Over a period of almost a year, the leaders participated in an online project, travelling together through email dialogue focused around leading, changing and meaning. In this, they experimented with a changing way of researching, developing a personalised space of changing in which they could truthtest their thoughts and feelings about the multiple facets of leading and meaning. Such a space - interstitial to their outer working and inner personal lives, but deeply connective of both - was found useful in supporting coherent change processes in the participant leaders. 